\title{
INFLUENCE OF DIFFERENT HERBAL-MIX FEED ADDITIVES ON SEROLOGICAL PARAMETERS, TIBIA BONE CHARACTERISTICS AND GUT MORPHOLOGY OF GROWING PIGS
}

\author{
Njoku, C. P. ${ }^{1}$, Sogunle, O. M. ${ }^{1}$, Adeyemi, O. A. ${ }^{1}$, Irekhore, O. T. ${ }^{2}$ \\ Mobolaji, O. O. ${ }^{1}$, Ayano, O. R. ${ }^{1}$ \\ ${ }^{1}$ Department of Animal Production and Health, \\ ${ }^{2}$ Agricultural Media Resources and Extension Centre (AMREC) \\ Federal University of Agriculture, Abeokuta \\ Nigeria \\ njokucp@funaab.edu.ng
}

\section{ABSTRACT}

A sixteen-week study was carried out in order to investigate the effects of different herbal-mix feed additives (Moringa, Basil and Neem) on serological parameters, tibia bone characteristics and gut morphology of growing pigs. Eighty-one Large White breed of pigs with a mean weight of $15.35 \pm 1.07$ were grouped on weight equalization basis into three treatments with 9 replicates per treatment and 3 pigs per replicate in a completely randomized design. Pigs on treatment 1 were fed a ration without integration of herbal-mix feed additives, those in treatments 2 and 3 were offered a diet that contained moringa-basil leaf meal and neem-basil leaf meal respectively. Blood samples were collected from the experimental pigs on the 12th week of the study for the determination of serum levels, while 1 pig from each replicate group whose weight was close to the mean replicate weight was chosen at the end of the study, fasted for 12 hours, sacrificed and the small intestine and left tibia bone were harvested and used for gut and bone morphology evaluation. These data generated from the study were subjected to a 1-way analysis of variance (ANOVA). The results indicated that herbal-mix feed additives influenced some of the serological parameters, i.e., globulin, glucose, total cholesterol, high- and low-density lipoproteins, and aspartate aminotransferase. These parameters decreased with integration of different herbal-mix in the pigs' diets except high density lipoprotein that increased statistically. The tibia characteristics such as tibia breaking strength, medial thickness and lateral thickness were also positively impacted by the dietary inclusion of the herbal-mix. Likewise, the villus height of the jejunum was positively enhanced by dietary inclusion of the herbal-mix feed additives. This study concluded that herbal-mix feed additives can be utilized in pigs' nutrition in enhancing some serological parameters, tibia bone and gut characteristics of growing pigs.

Key words: blood indices; feed additives; growing pigs; small intestine 


\section{INTRODUCTION}

The calls for the promotion of variable alternatives to modern health management practices need to be intensified as the rate of shortfalls in the supply of animal protein to the teeming world population continues to widen especially among resource-poor citizens of developing countries. The high cost and non-availability of chemically synthesized allopathic drugs among the local people that constitute the majority of the livestock farmers promote these shortfalls as pathogenic microbes prevails, leading to a high rate of mortality and morbidity [50]. It has been documented that about $80 \%$ of livestock producers in developing countries depends on traditional medicines as a means of animal health management and disease control $[28,51]$. Traditional medicine is an integral part of the ethnic group that have been passed from one generation to the next generation through practical experiences. The major advantages of this health practice are that they are cheap, readily available in pastoral areas and solve the problem of microbial resistance unlike commercial synthetic allopathic drugs. The development of resistant pathogenic microbes due to abuse of synthetic drugs, results in great concern over human health and environmental toxicity that leads to partial withdrawal and total ban in some parts of the world [42].

Most of Materia medica used in ethno-veterinary medicine is derived from plants [32]. The integration of herbal plants and their extracts into the ration of farm animals have been reported to enhance the productivity of the animal by improvement of the diet properties, quality of the produce from the animal, welfare of the animal and the general well-being of the animals [21]. Sh a hidi et al. [47] and Frankic et al. [10] promoted the prospects that herbs and spices with their extracts may serve as possible replacement of synthetic antibiotic growth enablers. Herbs and spices can be utilized as feed additives in livestock nutrition to improve feed intake, flavour and anti-oxidant properties due to the presence of multiple active ingredients and their mode of actions [9]. The integration of herbal plant parts in the form of leaf meal in the ration of livestock can assist in the reduction of feed cost, and total cost of production, thereby widening the profit margin of the rural livestock farmers. A study by $\mathrm{S}$ u gih a r to et al. [50] revealed that leaf meal contains high protein that can be used for partial replacement of expensive conven- tional plant protein sources like soya bean meal, groundnut cake, cotton seed meals, etc., in the diets of farm animals, especially among the resource poor rural dwellers of developing countries. Hence, the incorporation of herbal leaf meal in the diets of pigs will not only lead to higher profitability to pig farmer but also promote the health of the pigs.

There is a need to investigate and validate the properties of medicinal plants that have been used in traditional medicine with antimicrobial properties which can be integrated easily into the ration of farm animal in order to reduce the microbial loads and feed cost, and increase the livestock productivity by inserting its growth promoting effects in the animals. To this end, this study was carried out in order to evaluate the effects of herbal-mix feed additives on serological parameters, tibia bone and gut morphology of growing pigs.

\section{MATERIALS AND METHODS}

\section{Animal use and care}

The study protocol was approved by Animal Welfare Committee guideline of the Federal University of Agriculture, Abeokuta, Nigeria [11].

\section{Collection and preparation of herbal leaf blends}

Fresh matured moringa (Moringa oleifera), basil (Ocimum gratissimum) and neem (Azadirachta indica) leaves were harvested within the environment of Federal University of Agriculture, Abeokuta. The leaves were separated from the stems, spread in the shade and allowed to dry for 3-5 days without direct exposure to sunlight and turned constantly to avert the growth of fungi until they were crispy when touched, while still maintaining their greenish coloration. The leaves were packaged in jute sacks, sealed and kept within room temperature. They were later transported to commercial feed mill where they were milled into leaf meals and integrated into the various experimental diets. Blends of moringa-basil and neem-basil were obtained from mixing $5 \%$ moringa or neem with $1 \%$ basil. Three diets were formulated to meet the nutrient requirements of pigs such that diet 1 had no herbal leaf meal additives, while diets 2 and 3 contained moringa-basil and neem-basil leaf meals, respectively. The diets were formulated to meet with the recommended nutrient requirements for growing pigs 
as stipulated by NRC [37] with direct replacement of soybean meal and groundnut cake with equivalent herbal-mix leaf meals (weight for weight). The gross compositions and calculated analysis of the experimental diets are presented in Table 1.

Table 1. Percentage composition of experimental diets of growing pigs

\begin{tabular}{lccc}
\hline \multicolumn{1}{c}{ Ingredients [\%] } & Diet 1 & Diet 2 & Diet 3 \\
\hline Maize & 50 & 50 & 50 \\
Palm kernel cake & 10 & 10 & 10 \\
Basil leaf & 0 & 2 & 2 \\
Moringa leaf & 0 & 0 & 10 \\
Neem leaf & 0 & 10 & 0 \\
Soya bean meal & 18 & 8 & 8 \\
Groundnut cake & 9 & 7 & 7 \\
Fish meal & 2 & 2 & 2 \\
Wheat offal & 6.9 & 6.9 & 6.9 \\
Bone meal & 3 & 3 & 3 \\
Lysine & 0.3 & 0.3 & 0.3 \\
Methionine & 0.25 & 0.25 & 0.25 \\
*Premix & 0.3 & 0.3 & 0.3 \\
Salt (NaCl) & 0.25 & 0.25 & 0.25 \\
\hline TOTAL & 1000 & 100 & 100 \\
\hline Crude protein [\%] & 20.9 & 18.87 & 17.6 \\
\hline Ether extract [\%] & 4.56 & 4.84 & 4.49 \\
Crude fibre [\%] & 4.68 & 6.4 & 5.56 \\
\hline Ash [\%] & 3.05 & 3.54 & 3.1 \\
\hline & & & 2805.9 \\
\hline & 2834.59 & 2541.99 & \\
\hline & & & \\
\hline
\end{tabular}

*Premix to supply the following per kg diets; vitamin A 12600 IU; vitamin $D_{3} 2800$ IU; vitamin E 49 IU; vitamin K 32.8 mg; vitamin $B_{1} 1.4$ mg; vi$\operatorname{tamin} B_{2} 5.6 \mathrm{mg}$; vitamin $B_{6} 1.4 \mathrm{mg}$; vitamin $B_{12} 0.014$ mcg; niacin 21 mg; pantothenic acid $14 \mathrm{mg}$; folic acid $1.4 \mathrm{mg}$; biotin $0.028 \mathrm{mg}$; choline chloride 70 mg; manganese 70 mg; zinc 140 mg; iron 140 mg; copper 140 mg; iodine $1.4 \mathrm{mg}$; selenium $0.28 \mathrm{mg}$; cobalt $0.7 \mathrm{mg}$; antioxidant $168 \mathrm{mg}$

\section{Study area}

The study was carried out in 2019 at the piggery unit of the Teaching and Research Farm of the College of Animal Science and Livestock Production, Federal University of Agriculture, Abeokuta, Nigeria. The area lies between longitude $3^{\circ} 2^{\prime}$ East and latitude $7^{\circ} 10^{\prime}$ North [14]. The site is found in the derived savannah vegetation zone of
South-Western Nigeria. The annual mean precipitation rate of about $1100 \mathrm{~mm}$ with optimum rainfall recorded in the months of June to September. The ambient temperature ranges from $28^{\circ} \mathrm{C}$ in December to $36^{\circ} \mathrm{C}$ in February with the annual mean of relative humidity of $82 \%$.

\section{Experimental pigs and management}

A total of eighty-one (81) Large White weaner pigs with a mean weight of $15.35 \pm 1.07 \mathrm{~kg}$ were obtained from the existing stock in the Teaching and Research Farm of Federal University of Agriculture, Abeokuta. The pigs were grouped into 3 treatments based on the weight equalization method and later subdivided into 9 replicates of 3 pigs per replicate. The pigs were housed in individual pens with floor dimensions of $2 \mathrm{~m}$ by $2 \mathrm{~m}$ and equipped with concrete feeders and drinkers. The pens were open sided dwarf-walled of about 1.4-1.6 m high, which allowed for the adequate movement of air. All good management practices applicable to pigs were adhered to strictly.

\section{DATA COLLECTION}

\section{Serum parameters}

Blood samples were collected from 9 pigs per treatment ( 1 pig per replicate) on the 12 th week of the study and used for serological measurements. Serum was obtained after blood in plane sample bottle was allowed to stand for 2 hours at room temperature and centrifuged at 2000 r.p.m. for 10 minutes. The total serum protein was determined by the Biuret method and serum cholesterol was assessed by the enzymatic colorimetric technique [38]. The serum albumin was analysed by the colorimetric method according to $\mathrm{D} \mathrm{o} \mathrm{u} \mathrm{m}$ a and B rigs [7]. The globulin was estimated as the difference between the total serum protein and albumin. Serum glucose was estimated using a commercial glucose colorimetric assay kit (Cayman ${ }^{\circledR}$ Chemical Company, Ann Arbor, USA) and the protocol was followed according to the manufacturer's recommendation.

\section{Gut morphology}

At the end of the sixteenth week of the experiment, a total of twenty-seven (27) pigs consisting of nine (9) pigs per treatment whose weight were close to the replicate weight were selected, slaughtered and the small in- 
testines were removed for gut morphology. The pigs were weighed and fasted for 12 hours, and the fasted weight of each pig was taken before they were stunned by the percussion method and bled by incision using a sharp knife cutting through the jugular vein between the skull and the atlas. The complete bleeding and dehairing were done. The stomach of the pig was opened along the greater curvature and emptied. The digestive tract was removed and sections of the duodenum (approximately $10 \mathrm{~cm}$ from the stomach sphincter), the jejunum (5.5 $\mathrm{m}$ from the stomach sphincter), and the ileum (10 cm prior to the ileo-caecal orifice) were excised and opened along their length at the mesenteric border and a portion of each section was cut and put in a universal bottle containing $10 \%$ formalin and embedded in paraffin wax. These tissue samples were cut in transverse section in $5 \mu \mathrm{m}$ thick slices and were stained with haematoxylin and eosin. The villus height and width, were measured at 50× magnification using a calibrated eyepiece graticule earlier outlined by $\mathrm{H}$ a $\mathrm{l}$ a s et al. [16].

\section{Tibia bone morphology}

The left tibia bones of the pigs slaughtered and used for gut evaluation were collected and the adhering muscles and connective tissues were manually removed after they were dipped in boiling water for 5 minutes. The tibia length, medial thickness, and lateral thickness were determined with the aid of Vernier calliper, while the wet tibia bone weight and dry tibia bone weight were determined with the aid of a sensitive scale. While loss in tibia weight was obtained as difference between wet tibia weight and dry tibia weight. The bone breaking strength was determined using instron materials tester.

\section{RESULTS}

\section{Effects of herbal-mix feed additives on serological parameters of growing pigs}

Table 2 shows the effects of herbal-mix feed additives on serum parameters; globulin, glucose, total cholesterol, high density lipoprotein, low density lipoprotein and aspartate amino transferase were significantly $(\mathrm{P}<0.05)$ influenced by the herbal-mix feed additives. Pigs on diet without herbal-mix feed had the highest globulin value of $3.23 \mathrm{~g} \cdot \mathrm{dl}^{-1}$ followed by $3.08 \mathrm{~g} \cdot \mathrm{dl}^{-1}$ documented for pigs on neem-basil leaf meal supplemented ration while the least value of $2.43 \mathrm{mg} \cdot \mathrm{dl}^{-1}$ was recorded for pigs on moringa-basil leaf meal blend. Growing pigs on the control ration recorded the highest serum glucose value of $102.00 \mathrm{mg} \cdot \mathrm{dl}^{-1}$, followed by $92.83 \mathrm{mg} \cdot \mathrm{dl}^{-1}$ noted for pigs on the moringa-basil dietary treatment, while those on the ration containing neem-basil leaf meal had the least glucose

Table 2. Effects of herbal-mix feed additives on serological parameters of growing pigs

\begin{tabular}{|c|c|c|c|}
\hline Parameters & No herbal-mix & Moringa-basil & Neem-basil \\
\hline Total protein $\left[\mathrm{g} \cdot \mathrm{dl}^{-1}\right]$ & $7.00 \pm 0.32$ & $5.77 \pm 0.85$ & $6.90 \pm 0.27$ \\
\hline Albumin $\left[\mathrm{g} \cdot \mathrm{dl}^{-1}\right]$ & $3.77 \pm 0.23$ & $3.33 \pm 0.57$ & $3.82 \pm 0.14$ \\
\hline Globulin [g.dl-1] & $3.23 \pm 0.23^{\mathrm{a}}$ & $2.43 \pm 0.32^{b}$ & $3.08 \pm 0.24^{\mathrm{ab}}$ \\
\hline Glucose $\left[\mathrm{mg} \cdot \mathrm{dl}^{-1}\right]$ & $102.00 \pm 0.77^{\mathrm{a}}$ & $92.83 \pm 2.29^{b}$ & $86.67 \pm 1.63$ \\
\hline Urea $\left[\mathrm{mg} \cdot \mathrm{dl}^{-1}\right]$ & $5.43 \pm 0.49$ & $5.70 \pm 0.38$ & $5.23 \pm 0.15$ \\
\hline Creatinine $\left[\mathrm{mg} \cdot \mathrm{dl}^{-1}\right]$ & $0.63 \pm 0.67$ & $0.78 \pm 0.13$ & $0.82 \pm 0.90$ \\
\hline Total cholesterol [mg.dl-1 $\left.{ }^{-1}\right]$ & $94.83 \pm 1.56^{\mathrm{a}}$ & $86.83 \pm 1.30^{\mathrm{b}}$ & $85.67 \pm 3.21^{\mathrm{b}}$ \\
\hline Triglycerides $\left[\mathrm{mg}_{\mathrm{d}} \mathrm{dl}^{-1}\right]$ & $101.17 \pm 2.15$ & $97.83 \pm 1.58$ & $103.17 \pm 2.67$ \\
\hline High density lipoprotein [mg.dl-1"] & $40.68 \pm 1.43^{b}$ & $52.47 \pm 0.86^{\mathrm{a}}$ & $45.73 \pm 3.59^{t}$ \\
\hline Low density lipoprotein [mg.dl-1] & $24.97 \pm 1.42^{\mathrm{a}}$ & $21.17 \pm 1.21^{\mathrm{ab}}$ & $18.93 \pm 1.28^{b}$ \\
\hline Very low density lipoprotein $\left[\mathrm{mg} . \mathrm{dl}^{-1}\right]$ & $20.78 \pm 0.41$ & $19.53 \pm 0.58$ & $19.83 \pm 0.68$ \\
\hline Aspartate aminotransferase $\left[\mu \mathrm{U}^{-1} \mathrm{I}^{-1}\right]$ & $41.83 \pm 1.40^{\mathrm{a}}$ & $40.33 \pm 1.23^{\mathrm{a}}$ & $33.33 \pm 0.95^{\mathrm{b}}$ \\
\hline Alanine aminotransferase $\left[\mu \mathrm{U} . \mathrm{I}^{-1}\right]$ & $23.17 \pm 1.28$ & $22.92 \pm 2.10$ & $21.50 \pm 2.14$ \\
\hline
\end{tabular}

$a, b, c-$ Means with different superscript across the row differed significantly $(P<0.05)$ 
level of $86.67 \mathrm{mg} \cdot \mathrm{dl}^{-1}$. Pigs on a diet without herbal-mix feed additive had the highest significant total cholesterol value of $94.83 \mathrm{mg} \cdot \mathrm{dl}^{-1}$, while pigs on the ration containing moringa-basil and neem-basil leaf blends had comparable mean values of $86.83 \mathrm{mg} . \mathrm{dl}^{-1}$, respectively. The high-density lipoprotein was significantly $(\mathrm{P}<0.05)$ influenced by the herbal-mix feed additives with pigs on the ration containing moringa-basil feed additive had the highest value of $52.47 \mathrm{mg} \cdot \mathrm{dl}^{-1}$ and comparable mean high density lipo-

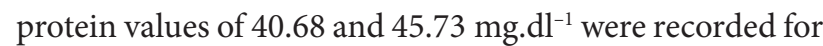
the pigs on the control diets and neem-basil leaf meals.

\section{Effects of herbal-mix feed additive on tibia bone morphology and strength of growing pigs}

Table 3 shows the effects of herbal-mix feed additives on tibia bone morphology and strength of growing pigs. Bone medial thickness, lateral thickness and bone breaking strength were significantly $(\mathrm{P}<0.05)$ influenced by

Table 3. Effects of herbal-mix feed additive on tibia bone characteristics of growing pigs

\begin{tabular}{lccc}
\multicolumn{1}{c}{ Parameters } & No herbal-mix & Moringa-basil & Neem-basil \\
\hline Wet tibia bone weight $[\mathrm{g}]$ & $97.84 \pm 5.50$ & $99.24 \pm 8.22$ & $99.24 \pm 6.35$ \\
Dry tibia bone weight $[\mathrm{g}]$ & $95.13 \pm 3.34$ & $96.53 \pm 4.11$ & $96.64 \pm 4.54$ \\
Loss in tibia bone weight [g] & $2.71 \pm 0.18$ & $2.71 \pm 0.91$ & $2.60 \pm 0.16$ \\
Tibia bone length [cm] & $15.38 \pm 0.31$ & $15.03 \pm 0.57$ & $15.55 \pm 0.32$ \\
Medial thickness [mm] & $26.72 \pm 1.32^{\mathrm{a}}$ & $21.92 \pm 1.91^{\mathrm{b}}$ & $22.10 \pm 0.99^{\mathrm{b}}$ \\
Lateral thickness [mm] & $43.42 \pm 1.84^{\mathrm{a}}$ & $40.39 \pm 1.93^{\mathrm{ab}}$ & $38.02 \pm 1.70^{\mathrm{b}}$ \\
Ash weight [g] & $34.17 \pm 3.00$ & $32.09 \pm 3.14$ & $27.86 \pm 0.43$ \\
Bone breaking force [N] & $20.02 \pm 0.73^{\mathrm{a}}$ & $17.52 \pm 0.28^{\mathrm{b}}$ & $13.55 \pm 1.14^{\mathrm{c}}$ \\
\hline
\end{tabular}

$a, b, c-M e a n s$ with different superscript across the row differed significantly $(P<0.05)$

Table 4. Effects of herbal-mix feed additives on the gut morphology of growing pigs

\begin{tabular}{llll}
\hline Parameters & No herbal-mix & Moringa-basil & Neem-basil \\
\hline \multicolumn{3}{c}{ Duodenum $[\mu \mathrm{m}]$} \\
\hline Villus height & $667.67 \pm 46.09$ & $691.67 \pm 30.05$ & $608.33 \pm 39.62$ \\
Apical width & $30.83 \pm 1.54$ & $29.83 \pm 1.17$ & $35.00 \pm 2.58$ \\
Basal width & $103.33 \pm 6.15$ & $95.83 \pm 5.54$ & $110.83 \pm 4.90$ \\
Lamina propria depth & $251.67 \pm 14.00$ & $236.67 \pm 13.82$ & $271.67 \pm 21.51$ \\
\hline & \multicolumn{1}{c}{ Jejunum $[\mu \mathrm{m}]$} & & \\
\hline Villus height & $595.00 \pm 15.86^{\mathrm{b}}$ & $641.67 \pm 30.05^{\mathrm{ab}}$ & $695.00 \pm 27.89^{\mathrm{a}}$ \\
Apical width & $42.50 \pm 1.71$ & $39.83 \pm 2.95$ & $40.00 \pm 2.24$ \\
Basal width & $115.00 \pm 6.19$ & $107.50 \pm 10.47$ & $115.83 \pm 5.23$ \\
Lamina propria depth & $240.00 \pm 14.38$ & $233.33 \pm 12.56$ & $238.33 \pm 14.00$ \\
\hline & \multicolumn{1}{c}{ lleum $[\mu \mathrm{m}]$} & & \\
\hline Villus height & $686.67 \pm 26.03$ & $606.67 \pm 29.06$ & $715.00 \pm 43.57$ \\
Apical width & $36.67 \pm 3.07$ & $38.33 \pm 2.11$ & $39.17 \pm 2.39$ \\
Basal width & $103.33 \pm 6.15$ & $116.67 \pm 6.15$ & $105.00 \pm 7.53$ \\
\hline & $240.00 \pm 15.28$ & $256.67 \pm 24.04$ & $256.67 \pm 22.61$ \\
\hline
\end{tabular}

a, c - Means with different superscript across the row differed significantly $(P<0.05)$ 
the herbal-mix feed additives. Pigs on the diet without herbal-mix feed additive had the highest breaking force of $20.02 \mathrm{~N}$ followed by $17.52 \mathrm{~N}$ documented for pigs on the moringa-basil leaf meal supplemented ration while the least value of $13.55 \mathrm{~N}$ was recorded for pigs on the ration containing neem-basil leaf meal. The growing pigs on the control ration recorded the highest medial thickness of $26.72 \mathrm{~mm}$ followed by $22.10 \mathrm{~mm}$ documented for pigs on the neem-basil, while those on the ration containing moringa-basil leaf blend had the least medial thickness of $21.92 \mathrm{~mm}$. The highest lateral thickness $(43.42 \mathrm{~mm})$ was recorded for pigs on the diet with no herbal leaf meal while those on neem-basil leaf meal supplemental diet had the least lateral thickness of $38.02 \mathrm{~mm}$.

\section{Effects of the herbal-mix feed additives on the gut morphology of growing pigs}

The effects of the dietary inclusion of the herbal-mix on gut morphology of growing pigs is shown in Table 4 . The dietary inclusion of the herbal-mix feed additive had no significant effect in all gut morphological parameters considered in the present study except for the jejunum villus height. Growing pigs subjected to dietary inclusion of the neem-basil blend recorded the highest jejunum villus height followed by their counterparts on the ration that contained moringa-basil leaf meal while those on the diet that had no herbal-mix feed additive recorded the least villus height of $595.00 \mu \mathrm{m}$.

\section{DISCUSSION}

The health conditions of farm animals like pigs can be estimated from the blood parameters. The blood indices indicate the physiological state and nutritional status of the pig's body. The result of this study revealed variations in the dietary crude protein fed to the growing pigs. This must have resulted due to the significant lower globulin values recorded for pigs on diets containing herbal leaf blends which had lower dietary crude protein contents with range values of $17.60 \%$ to $18.87 \%$ compared to $20.90 \%$ of the control ration. The lower dietary crude protein content of the ration with herbal-mix feed additives must have resulted to deficit intake of amino acids [6]. According to the observation of A w o s a n y a et al. [4], the level of blood protein is contingent upon the quality and quantity of the dietary protein intake of the farm animal. The observation of this study is consistent with the studies of A t ti a et al. [3] and Li u et al. [27] that reported significantly lower plasma total protein and globulin levels with decreasing levels of the dietary crude protein content. In contrast, $\mathrm{M}$ a h m o u d et al. [29] observed a decrease in alpha-globulin and albumin to globulin ratio with increasing levels of dietary crude protein contents of laying birds. These differences in this present result with that of $\mathrm{M} \mathrm{a} \mathrm{h} \mathrm{m} \mathrm{o} \mathrm{u} \mathrm{d} \mathrm{et} \mathrm{al.} \mathrm{[29]} \mathrm{may} \mathrm{be} \mathrm{due} \mathrm{to} \mathrm{genotype} \mathrm{or} \mathrm{geno-}$ type $\mathrm{x}$ diet interactions [30].

The inclusion of herbal leaf blend in the ration of pigs had remarkable serum glucose reduction in pigs when compared with the value noted for pigs on the control ration. This reduction in the serum glucose points to the presence of hypoglycaemic properties of the herbal plants. According to Kappel et al. [20] and Oleforuh O k o le h et al. [39] the presence of phytochemical compounds in leaf meal enhances the carbohydrate metabolism of farm animals. S a u va i r e et al. [45] and S ch ryve r [46] linked the reduction of serum glucose in animals fed fenugreek seed to direct S-cells production that secrete secretin from the duodenum and jejunum which stimulate exocrine pancreatic secretion of amino acid (4-hydroxy isoleucine) that improves insulin production, thereby resulting to higher glucose tolerance levels.

Our results showed a significant reduction in total cholesterol and low-density lipoprotein, but increased the high-density lipoprotein. The significant lower total cholesterol and low-density lipoprotein levels in pigs fed rations containing herbal-mix feed additives compared with the value documented for their counterparts on control diet, could indicate the presence of hypolipidemic agent in the leaf meal. It has been reported that moringa has high phytosterol that reduces the cholesterol contents of meat, egg and serum [19]. It contains bioactive compounds like flavonoids and phenolic compounds with antioxidant potentials that assist in the synthesis of bile salts needed for fats emulsification and the reduction in lipids absorption thereby decreasing serum cholesterol [19, 36, 49]. Also, Ghazaiah and Ali [12] associated the hypocholesterol properties in animals fed diets containing leaf meals to defatted components of the leaves with high fibre contents that can obstruct intestinal cholesterol absorption.

Serum enzymes like Aspartate aminotransferase (AST) and Alanine aminotransferase (ALT) are involved in the 
metabolism of amino acid and can be used in determining the functionality status of liver [13]. Our study showed a significant reduction in the serum AST levels of the pigs on herbal-mix feed additives compared to the results obtained for the pigs on the control diet. This result implies that the herbal-mix feed additives exerts a protective influence on the liver without inducing visible toxicity. C h o u d h u ry et al. [5] observed that herbal extracts reduced liver enzymes (Alanine transaminase and Aspartate transaminase) in the plasma and attributed this fact to the existence of numerous hepatoprotective constituents in the plants.

The state of the bone is unswervingly linked to the bioavailability of calcium and phosphorus levels. The commonest indices utilized in determining the bioavailability of calcium and phosphorus are the ash contents and bone breaking strength [48]. Our study showed that the medial thickness, lateral thickness and breaking strength of the bone decreased statistically with the integration of different herbal-mix feed additive; with the most impact observed in pigs on ration containing blends of neem-basil. The decreasing tibia morphological values with different integration of blends of herbal plants suggests poor mineralisation of the bone due to the presence of anti-nutritional factors that must have stalled protein synthesis, digestion and mineral absorption in the digestive tract of the animal [31] resulting in the increased excretion of calcium from its body [41]. Another possible explanation for the decreasing tibia values as observed in our study could be linked to the quantity of crude protein available in the diets fed to the pigs which appeared to be least in the ration with neem-basil leaf blends as depicted by the calculated composition of the experimental diets. The health status of the bone can be assessed through bone length, weight and the percentage of ash content [52], which in turn is subject to the mineral composition of the bone [15]. H e a n e y and L a y m a [18] depicted that many factors have been identified to impact the health of bone; among them are dietary protein content and the source of the protein which could have positive or negative impact on: the bone, calcium intake, weight loss and acid/base of the diet. High dietary protein intake has been said to have an effect on calcium homeostasis which can influenced the excretion of calcium. A l b right et al. [2] as quoted by $\mathrm{H}$ e a n e y and Laym a n [18] articulated that diets with insufficient protein results in a negative nitrogen bal- ance that could have impaired the possibility of osteoblasts to deposit the necessary organic matrix required in bone formation. The authors argued that some of the osteopathies linked with deficiencies of calcium and phosphorus in the ration of farm animals could have resulted from dietary protein shortage rather than the minerals. L e a $\mathrm{ch}$ and L i l b u m [23] observed that long bones like the tibia experience cellular sensitivity to multiple dietary inadequacies. The statistical differences noted in the tibia bone breaking strength which reduced with dietary integration of herbal-mix feed additives is at variance with the study of $\mathrm{N} \mathrm{k} \mathrm{u} \mathrm{k} \mathrm{w} \mathrm{a} \mathrm{n} \mathrm{a} \mathrm{et} \mathrm{al.} \mathrm{[35]} \mathrm{that} \mathrm{observed} \mathrm{comparable} \mathrm{means}$ in bone breaking strength of broiler chickens fed diets with different inclusion levels of Moringa oleifera leaf meals. On the other hand, our study concurred with the summation of R e h m a n et al. [43] that dietary inclusion of herbal plants improved the indices of tibia bone of broiler chickens. The statistical variation in bone breaking strength in our study could be linked to the presence of caffeic acid in herbal plants used in the formulation of the diets fed to the pigs which must have resulted in higher osteoporosis that leads to less tensile strength of the bone, thereby requiring less breaking force [43].

Digestion and absorption of nutrients taken into the body of farm animals, occurs mostly in the small intestine of the animal. From the study of $\mathrm{R} \mathrm{u} t \mathrm{t}$ a $\mathrm{n}$ a v u t et al. [44], it was stated that the growth rate and intestinal performance were a result of the functionality of the intestinal villus and epithelial cell structures. Likewise, $\mathrm{Me} \mathrm{k} \mathrm{b} \mathrm{u} \mathrm{n} \mathrm{g} \mathrm{w} \mathrm{a} \mathrm{n} \mathrm{et} \mathrm{al.}$ [33] and Pappenheime r and Michel [40] stated that there is a positive correlation between the height of the villi and the rate of intestinal digestibility and absorption of nutrients. The statistical higher difference noted in the jejunum villus height of pigs on rations containing herbal-mix feed additives points to the fact that herbal plants contained an active ingredient that could have initiated cell proliferation $[17,22]$; hence, improving the absorptive capacity of the intestine by increasing the surface area for nutrient absorption. L i u et al. [26] affirmed that the integration of Capsicum oleoresin, Turmeric oleoresin or garlic in the diet of weanling pigs improved the gut health by increasing intestinal villi height, gut barrier function, and integrity. Likewise, Mich i els et al. [34] concluded that the inclusion of carvacrol and thymol in pig's rations led to a decline in the number of intra-epithelial lymphocytes and improvement in the villus height/crypt depth in the distal 
small intestine. The improvement in the jejunum height could also be linked to higher fibre content in the diets with range values of $4.68-6.40 \%$; higher values were obtained in diets with herbal-mix feed additives which must have enhanced the gut health of the pigs. Le S c i ello u r [24] surmised that there is an increasing evidence indicating that fibre could have prebiotic properties in pigs as a result of its interaction with gut micro-environment and the associated gut immune systems. L i n d b e r g [25] listed the merits of dietary fibre which includes its ability to stimulate gut health, increase the satiety in pigs, and affect pig behaviour and general well-being of the pigs. F a $\mathrm{n} g$ et al. [8] and A debiyi et al. [1] reported statistical increases in villus height in animals on dietary inclusion of photogenic plant parts.

\section{CONCLUSIONS}

Our study showed that dietary inclusion of different herbal-mix feed additives had an impact on serum parameters (Globulin, glucose, total cholestero, high- and low-density lipoproteins and aspartate aminotransferase), tibia morphometric (medial and lateral thickness and bone breaking strength) and jejunum villus height of growing pigs. It is therefore recommended that for sustainable food security in developing countries of the world, herbal-mix feed additives should be integrated in the ration of growing pig in order to enhance their general well-being and as well as reduce the cost of feeding among rural livestock keepers; however, caution must be taken as it can lead to poor bone mineralization at higher inclusion levels.

\section{REFERENCES}

1. Adebiyi, O. A., Ajayi, O. S., Adejumo, I. O., Osungade, T. O., 2014: Performance, microbial load and gut morphology of weaned pigs fed diets supplemented with turmeric, ginger and garlic extracts. Trop. Anim. Prod. Invest., 17, 1, 25-31.

2. Albright, F., Smith, P. H., Richardson, A. M., 1941: Postmenopausal osteoporosis: Its clinical features. Am. Med. Assn., 116, 2465-2474.

3. Attia, Y. A., Bovera, F., Abd-El-Hamid, A. E., Tag EL-Din, A. E., Al-Harthi, M. A., Nizza, A., Elharidy, R. M., 2017: Effect of dietary protein concentrations, amino acids and conjugated linoleic acid supplementations on productive performance and lipid metabolism of broiler chicks. Ital. J. Anim. Sci., 16, 4, 563-572. DOI: 10.1080/1828051X.2017.1301228.

4. Awosanya, B., Joseph, J. K., Apata, D. F., Agboola, M. A., 1999: Performance, blood chemistry and carcass quality attribute of rabbits fed raw and processed pueraria seed meal. Trop. J. Anim. Sci., 2, 2, 89-96. DOI: 10.4314/tjas.v212. 49687.

5. Choudhury, S., Rahaman, C. H., Mandal, S., 2009: Studies on leaf epidermal micromorphology, wood element characters and phytochemical screening of three medicinally important taxa of the family Convolvulaceae. J. Environ. Sociobiol., 6, 2, 105-118. DOI: 10.1055/s-0029-1235011.

6. Corzo, A., Loar II, R. E., Kidd, M. T., 2009: Limitations of dietary isoleucine and valine in broiler chick diets. Poult. Sci., 88, 1934-1938. DOI: 10.3382/ps.2009-00109.

7. Douma, B. T., Briggs, H. G., 1972: Serum albumin by bromocresol green binding stand. Meth. Clin. Chem., 7, 175-179.

8. Fang, J., Yan, F. Y., Kong, X. F., Ruan, Z., Liu, Z. Q., Huang, R. L., Li, T. J., Geng, M. M., et al., 2009: Dietary supplementation with Acanthopanax senticosus extract enhances gut health in weaning piglets. Livest. Sci., 123, 268-275. DOI: 10.1016/j.livsci.2008.11.020.

9. Figen, K., Bora-Unlu, H., Guven, O., 2011: Effects of oregano and garlic essential oils on performance, carcass, organ and blood characteristics and intestinal microflora of broilers. Livest. Sci., 137, 219-225. DOI: 10.1016/j.livsci.2010.11.010.

10. Frankic, T., Voljg, M., Salobir, J., Rezar, V., 2009: Importance of medical herbs in animal feeding: A review. Acta. Agric. Slovenica, 92, 95-95.

11. FUNAAB, 2013: Policy on Research of the Federal University of Agriculture. Abeokuta. Nigeria. http://www.unaab.edu.ng (04/06/2016).

12. Ghazalah, A. A., Ali, A. M., 2008: Rosemary leaves as a dietary supplement for growth in broiler chickens. Intern. J. Poult. Sci., 7, 234-239. DOI: 10.3923/ijps.2008.234.239.

13. Giannini, E. G., Testa, R., Savarino, V., 2005: Liver enzyme alteration: a guide for clinicians. Canad. Med. Assn. J., 172, 3, 367-379. DOI: 10.1503/cmaj.1040752.

14. Google Earth, 2018: http;//www.google.com.

15. Hafeez, A., Mader, A., Boroojeni, F. G., Ruhnke, I., Röhe, I., Männer, K., Zentek, J., 2014: Impact of thermal and organic acid treatment of feed on apparent ileal mineral absorption, tibial and liver mineral concentration, and tibia quality in broilers. Poult. Sci., 93, 1754-1763. DOI: 10.3382/ ps.2013-03750. 
16. Halas, D., Hansen, C. F., Hampson, D. J., Kim, J. C., Mullan, B. P., Wilson, R. H., Pluske, J. R., 2010: Effects of benzoic acid and inulin on ammonia-nitrogen excretion, plasma urea levels, and the $\mathrm{pH}$ in faeces and urine of weaner pigs. Livest. Sci., 134, 243-245. DOI: 10.1016/j.livsci.2010.06.153.

17. Hanczakowska, E., Swiatkiewicz, M., 2012: Effect of herbal extracts on piglet performance and small intestinal epithelial villi. Czech J. Anim. Sci., 57, 9, 420-429. DOI: 10.17221/6316CJAS.

18. Heaney, R. P., Layman, D. K., 2008: Amount and type of protein influences on bone health. Am. J. Clin. Nutr., 87 (Supplement), 1567-1570. DOI: 10.1093/ajcn/87.5.15675.

19. Hussain, W., Ullah, A., Hussain, J., Hussain, S., Shinwari, Z. K., Ibrar, M., 2014: Ethno-medicinal plants of Tahsil Barawal Bandi Dir Upper Khyber Pakhtunkhwa Pakistan. J. Appl. Pharma. Sci., 4, 7, 94-97. DOI: 10.7324/JAPS.2014.40716.

20. Kappel, V. D., Zanatta, L., Postal, B. G., Silva, F. R. M. B., 2013: Rutin potentiates calcium uptake via voltage-dependent calcium channel associated with stimulation of glucose uptake in skeletal muscle. Arch. Biochem. Biophys., 532, 5560. DOI: 10.1016/j.abb.2013.01.008.

21. Kołodziej-Skalska, A., Rybarczyk, A., Matysiak, B., Jacyno, E., Pietruszka, A., Kawęcka, M., 2011: Effect of dietary plant extracts mixture on pork meat quality. Acta Agric. Scand. Sect. A. Anim. Sci., 6, 80-85. DOI: 10.1080/09064702.2011.599860.

22. Lauronen, J., Pakarinen, M. P., Kuusanmakai, P., Savilahti, E., Vento, P., Paavonen, T., Halttunen, J., 1998: Intestinal adaptation after massive proximal small-bowel resection in the pig. Scand. J. Gastroentero., 33, 152-158. DOI: 10.1080/ 00365529850166879.

23. Leach Jr., R. M., Lilburn, M. S., 1992: Current knowledge on the etiology of tibial dyschondroplasia in the avian species. Poult. Sci. Rev., 4, 57-65.

24. Le Sciellour, M., Labussière, E., Zemb, O., Renaudeau, D., 2018: Effect of dietary fibre content on nutrient digestibility and faecal microbiota composition in growing-finishing pigs. PLOS ONE, 13, 10, e0206159. DOI: 10.1371/journal.pone. 0206159.

25. Lindberg, E., 2014: Fibre effects in nutrition and gut health in pigs. J. Anim. Sci. Biotech., 5, 1, 15-23. DOI: 10.1186/20491891-5-15.

26. Liu, Y., Song, M., Che, T. M., Almeida, J. A. S., Lee, J. J., Bravo, D., et al., 2013: Dietary plant extracts alleviate diarrhoea and alter immune responses of weaned pigs experimentally infected with a pathogenic Escherichia coli. J. Anim. Sci., 91, 11, 5294-5306. DOI: 10.2527/jas.2012-6194.
27. Liu, S. K., Niu, Z. Y., Min, Y. N., Wang, Z. P., Zhang, J., He, Z. F., et al., 2015: Effect of dietary crude protein on the growth performance, carcass characteristics and serum biochemical indices of Lueyang black-boned chickens from seven to twelve weeks of age. Rev. Bras. de Cienc. Avic., 17, 1, 103-108. DOI: 10.1590/1516-635x1701103-108.

28. Luseba, D., Tshisikhawe, M. P., 2013: Medicinal plants used in the treatment of livestock diseases in Vhembe region, Limpopo Province, South Africa. J. Med. Plants Res., 7, 10, 593-601. DOI: 10.5897/JMPR012.1213.

29. Mahmoud, A., Mohamed, E. A. E., Mayada, R. F., Ruchi, T., Swan, S., Kumaragurubaran, K., Kuldeep, D., 2016: Positive and negative impacts of dietary protein levels in laying hens. Asian J. Anim. Sci., 10, 2, 165-174. DOI: 10.3923/ajas. 2016.165.174.

30. Marks, H. L., 1990: Genotype by diet interactions in body and abdominal fat weight in broilers. Poult. Sci., 69, 879-886. DOI: $10.3382 /$ ps.0690879.

31. Mbikay, M., 2012: Therapeutic potential of Moringa oleifera leaves in chronic hyperglycemia and dyslipidaemia: A review. Front. Pharmacol., 3, 1-12. DOI: 10.3389/fphar.2012.00024.

32. McCorkle, C. M., 1986: An introduction to ethno-veterinary research and development. J. Ethno-biol., 6, 129-149.

33. Mekbungwan, A., Yamauchi, K., Sakaida, T., Buwjoom, T., 2008: Effects of a charcoal powder-wood vinegar compound solution in piglets for raw pigeon pea seed meal. Animal, 2, 366-374. DOI: 10.1017/S1751731107001243.

34. Michiels, J., Missotten, J., Van Hoorick, A., Ovyn, A., Fremaut, D., De Smet, S., Dierick, N., 2010: Effects of dose and formulation of carvacrol and thymol on bacteria and some functional traits of the gut in piglets after weaning. Arch. Anim. Nutr., 64, 136-154. DOI: 10.1080/17450390903499915.

35. Nkukwana, T. T., Muchenje, V., Masika, P. J., Hoffman, L. C., Dzama, K., 2014: The effect of Moringa oleifera leaf meal supplementation on tibia strength, morphology and inorganic content of broiler chickens. South African J. Anim. Sci., 44, 3, 228-239. DOI: 10.4314/sajas.v44i3.4.

36. Nobakht, A., Mogaddam, M., 2013: The effects different levels of customary (Tanacetum balsamita) medicinal plant on performance, egg traits and blood biochemical parameters of laying hens. Iranian J. Appl. Anim. Sci., 3, 307-312. http:// ijas.iaurasht.ac.ir/article_516037_0f15ee00f75e1215b288cfaa589a7253.pdf.

37. National Research Council (NRC) 1998: Nutrient Requirement of Swine (10th Revised Edn.). Subcommittee on Animal Nutrition, National Research Council, 210 pp. 
38. Odoh, L. I., Bratte, L., 2015: Effect of varying level of neem (Azadirachta indica) leaf meal in layer diet on the haematological and serological indices and faecal bacterial counts of layers. J. Natural Sci. Res., 5, 4, 37-44. https://core.ac.uk/ download/pdf/234655629.pdf.

39. Oleforuh-Okoleh, V. U., Ndofor Foleng, H. M., Olorunleke, S. O., Uguru, J. O., 2015: Evaluation of growth performance, haematological and serum biochemical response of broiler chickens to aqueous extract of ginger and garlic. J. Agric. Sci., 7, 4, 167-173. DOI: 10.5539/jas.v7n4p167.

40. Pappenheimer, J. R., Michel, C. C., 2003: Role of villus microcirculation in intestinal absorption of glucose: Coupling of epithelial with endothelial transport. J. Physiol., 553, 2, 561-574. DOI: 10.1113/jphysiol.2003.043257.

41. Parikh, P., Patel, C., Rangrez, A., 2015: Osteoprotective effect of different components of Moringa oleifera in ovariectomy induced osteoporosis model of Wistar rats. Europ. J. Biomed. Pharma. Sci., 2, 3, 1179-1196.

42. Rajput, Z. I., Xiao, C. W., Hu, S. H., Arijo, A. G., Soomro, N. M., 2007: Improvement of the efficacy of influenza vaccination $(\mathrm{H} 5 \mathrm{~N} 1)$ in chicken by using extract of Cochinchina momordica seed (ECMS). J. Zhejiang University Sci. B., 8, 331-337. DOI: 10.1631/jzus.2007.B0331.

43. Rehman, H. F., Masood, S., Yousaf, M. S., Ashraf, S., Khan, I., Shah, M., et al., 2018: Effect of Moringa oleifera leaf powder supplementation on pectoral muscle quality and morphometric characteristics of tibia bone in broiler chickens. Braz. J. Poult. Sci., 20, 4, 817-824. DOI: 10.1590/18069061-2017-0609.

44. Ruttanavut, J., Yamauchi, K., Goto, H., Erikawa, T., 2009: Effects of dietary bamboo charcoal powder including vinegar liquid on growth performance and histological intestinal change in Aigamo ducks. Inter. J. Poult. Sci., 8, 229-236. DOI: 10.3923/ijps.2009.229.236
45. Sauvaire, Y., Petit, P., Broca, C., Manteghetti, M., Baissac, Y., Fernandez-Alvarez, J., et al., 1998: 4-Hydroxyisoleucine, a novel amino acid potentiator of insulin secretion. Diabetes, 47, 206-210. DOI: 10.2337/diab.47.2.206.

46. Schryver, T., 2002: Fenugreek. Total Health, 24, 42-44.

47. Shahidi, F., Janitha, P. K., Wanasundara, P., 1992: Phenolic antioxidants. Crit. Rev. Food Sci. Nutr., 32, 67-102. DOI: $10.1080 / 10408399209527581$.

48. Shaw, A. L., Blake, J. P., Moran, E., 2010: Effects of flesh attachment on bone breaking and of phosphorus concentration on performance of broilers hatched from young and old flocks. Poult. Sci., 89, 295-302. DOI: 10.3382/ps.2009-00402.

49. Srinivasan, K., 2005: Plant foods in the management of diabetes mellitus: Spices as beneficial antidiabetic food adjuncts. Inter. J. Food Sci. Nutr., 56, 399-414. DOI: 10.1080/ 09637480500512872

50. Sugiharto, S., Isroli, I., Yudiarti, T., Widiastuti, E., Wahyuni, H. I., Sartono, T. A. 2018: Performance, physiological and microbiological responses of broiler chicks to Moringa oleifera leaf powder, garlic powder or their combination. Livest. Res. Rur. Dev., 30, 12. http://www.lrrd.org/lrrd30/12/ sgh_u30209.html.

51. World Health Organization (WHO), 2002: World Health Organization Monographs on Selected Medicinal Plants, Volume 2, Geneva. 358 pp. https://apps.who.int/iris/handle/ $10665 / 42052$.

52. Ziaie, H., Bashtani, M., Karimi-Torshizi, M. A., Naeeimipour, H., Farhangfar, H., Zeinali, A., 2011: Effect of antibiotic and its alternatives on morphometric cha racteristics, mineral content and bone strength of tibia in Ross broiler chickens. Global Vet., 7, 315-323.

Received September 22, 2020

Accepted December 13, 2020 